\title{
ANALISIS PENETAPAN DISPENSASI KAWIN DALAM PERSPEKTIF UNDANG- UNDANG PERLINDUNGAN ANAK (STUDI KASUS DI PENGADILAN AGAMA LIMBOTO
}

\author{
Sri Rahmawaty Yunus dan Ahmad Faisal
}

\begin{abstract}
This thesis described the establishment of judge in Limboto Religious Court in adjudicating marriage dispensation proposal. The proposal was requested by the parents for the children's underage marriage, while in marriage law chapter 7 says that the marriage can be arranged at the age of 19 years old for men and 16yeras for women. Meanwhile, children under 18 years old should have protection on that rights and welfare as stated in Child Protection Law. Therefore, this research was conducted based on big concern on violation of children's rights.

In this research, the researcher discussed problems on 1) how the judges considered the marriage dispensation proposal in Limboto Religious Court? And 2) how the judges determined the marriage dispensation proposal?

This thesis was conducted through field research by means a research done in a particular location at area, and in this case it was located in Limboto Religious Court. This research used descriptive -analytic method where the problem of research was solved by describing and analytic it through data collection, composition, data analysis, data presentation and assessment on the research problem.

The result showed that the implementation of marriage dispensation in Limboto Religious Court is relevant with legal substance of child protection law as well as marriage law number 1 of 1974 in which it is based on principle of the law, it also prioritizes welfare of the children who are mature enough in building a new family. Those children in marriage dispensation have met stands in child protection that puts forward the regulation's best principle, the right to live, and appreciation for the children. Therefore, the marriage dispensation in Limboto Religious Court is not contradictory to the child protection law.
\end{abstract}

Keywords: marriage dispensation, child's priority, and child protection 


\section{A. Pendahuluan}

Perkawinan dibawah umur masih dilakukan oleh para orang tua, khususnya di beberapa kawasan Nusantara akibat pengaruh adat kebiasaa setempat. Anak-anak yang belum matang jiwa raganya, dijodohkan oleh orang tua, tanpa mereka itu tahu arti dan makna perkawinan yang dilakoninya. Pada peristiwa itu justru kehendak dan kepentingan orang tua yang dijadikan batu ukur, tanpa mempedulikan kebutuhan anak yang masih terlalu muda untuk membangun keluarga. Berdasar pertimbangan medis, ada kalanya perkawinan dibawah umur itu tidak sehat, baik ditinjau dari segi fisik ataupun mental yang bersangkutan.

Menikah dibawah umur sangat rentang terhadap timbulnya berbagai kerusakan dalam kehidupan rumah tangga yang dibentuknya, sehingga bisa berakibat tidak tercapainya tujuan perkawinan. Dari sudut pandangan kedokteran, pernikahan dibawah umur mempunyai dampak negatif baik bagi ibu maupun anak yang akan dilahirkan. Begitupula ditinjau dari sisi sosial, bahwa perkawinan dibawah umur dapat mengurangi harmonisasi keluarga, karena emosi yang masih labil antara suami dan istri yang dapat menyebabkan hilangnya kontrol dalam menyelesaikan permasalahan keluarga.

Dengan kata lain, nikah dibawah umur bisa bertentangan dengan tujuan hukum islam. Pada keadaan dilematis ini, hakim Pengadilan Agama Limboto sebagai pihak yang berwenang dituntut untuk memutuskan mana yang lebih masalah anatara nikah dibawah umur dengan membiarkan mereka terjerumus kedalam perzinahan. Di negara Indonesia, Undang-undang Perlindungan anak No. 23 tahun 2002 telah mengatur pola perlindungan anak yang didalammya mencakup hak dan kewajiban anak tersebut. Dalam pasal 1 disebutkan kategori anak yaitu Anak adalah seorang yang belum berusia 18 (delapan belas) tahun, termasuk anak yang masih dalam kandungan. Dalam pasal 2 menyebutkan tujuan dari perlindungan ini yakni Perlindungan anak adalah segala kegiatan untuk menjamin dan melindungi anak dan hak-haknya agar dapat hidup, tumbuh, berkembang dan berpartisipasi, secara optimal sesuai dengan harkat dan martabat kemanusian, serta mendapat perlindungan dari kekerasan dan diskriminasi.

Undang-undang Perkawinan No.1 tahun 1974, sebagaimana dijelaskan dengan bertujuan untuk mencegah terjadinya perkawinan anak-anak, agar pemuda-pemudi yang akan menjadi suami-istri benar-benar telah masak jiwa raganya dalam membentuk keluarga/rumah tangga yang bahagia dan kekal. Begitu pula dimaksudkan untuk dapat mencegah terjadinya perceraian muda dan agar dapat membenihkan keturunan yang baik dan sehat, serta tidak berakibat laju kelahiran yang lebih tinggi sehingga mempercepat pertambahan penduduk.2

Usia yang telah ditetapkan oleh Undang-undang perkawinan dalam pasal 7 ayat (1) merupakan batasan minimal khusus dalam pernikahan. Sedangkan kalau dikaitkan dengan kategori yang lain misalnya mengenai perlindungan anak, maka batasan usia bagi khusus wanita, akan berbenturan dengan ketentuan pasal 1 ayat (1) Undang-undang Nomor 23 Tahun 2002 tentang perlindungan anak yang menyebutkan bahwa "anak adalah seorang yang belum berusia 18 (delapan belas) tahun, termasuk anak yang dalam kandungan". 3

Penjelasan Undang-undang Perkawinan pada Pasal 7 menentukan bahwa "untuk menjaga kesehatan suami istri dan keturunan, perlu ditetapkan batas-batas umur untuk 
menikah".4 Undang-undang tersebut menganut prinsip bahwa calon suami istri harus telah matang jasmani dan rohani untuk melangsungkan perkawinan, untuk dapat memenuhi tujuan luhur dari perkawinan dan akan mendapatkan keturunan yang baik dan sehat. Oleh sebab itu harus dicegah adanya perkawinan dibawah umur. Perkawinan itu sendiri mempunyai hubungan erat dengan masalah kependudukan, karena ternyata bahwa batas umur yang lebih rendah bagi wanita untuk menikah, mengakibatkan laju kelahiran yang lebih tinggi.

Melihat fakta sekarang ini, perkawinan dibawah umur akan semakin meningkat walaupun Undang-undang perkawinan masih memberikan kelonggaran kepada orang yang ingin menikah. Akan tetapi bagi mereka yang ingin mendapatkan izin dispensasi kawin dari Pengadilan Agama dapat memberikan alasan yang tepat mengenai apa alasan mereka menikah diusia dini. Apakah alasan tersebut dapat diterima dan memenuhi kriteria atau tidak, karena jika semua orang yang mengajukan dispensasi kawin dikabulkan, maka secara otomatis tidak memenuhi apa yang telah ditetapkan oleh Undang-undang No. 1 tahun 1974.

Faktor lain yang mengakibatkan terjadinya perkawinan dibawah umur yaitu pendidikan yang rendah, sebagian besar pelaku nikah dibawah umur terlebih dahulu telah mengalami putus sekolah. Orang tua seharusnya menjadi pihak yang bertanggung jawab atas pendidikan anak, terkadang sering mengabaikan pendidikan anaknya. Hal tersebut dimungkinkan orang tua yang seharusnya menjadi pengayom dan contoh bagi anak-anak mereka, memiliki tingkat pendidikan yang rendah bahkan ada orang tua yang sama sekali tidak pernah mengenyam pendidikan secara formal.

Meskipun Undang-undang telah menetapkan batasan usia perkawinan sedemikian rupa, namun tidak menutup kemungkinan seorang menikah dibawah umur tersebut. Seseorang yang belum mencapai umur yang ditetapkan tetap dapat melakukan perkawinan dengan syarat mendapatkan izin dari walinya dan dari Pengadilan Agama. Di Pengadilan Agama permohonan izin menikah ini disebut dengan permohonan Dispensasi Kawin.

Dispensasi kawin secara absolut memang menjadi kompetensi Pengadilan Agama berdasarkan ketentuan Pasal 2 ayat (2) jis pasal 63 UU. No. 1 Tahun 1974, pasal 49 huruf (a) UU No. 7 Tahun 1989 yang telah diubah dengan UU Nomor 3 Tahun 2006 dan perubahan kedua dengan UU No. 50 tahun 2009. Dalam hal ini, ketika seorang belum mencapai batas minimal usia yang diizinkan oleh Undang-undang untuk perkawinan, yaitu 19 tahun bagi calon mempelai pria dan 16 tahun bagi calon wanita. Dengan kata lain, apabila seseorang ingin melangsungkan perkawinan sementara usianya belum mencapai batas usia minimal tersebut, maka dia harus mengajukan dispensasi kawin ke Pengadilan Agama.

Berbagai macam alasan permohonan dispensasi perkawinan diajukan oleh para pihak yang berkepentingan, di antaranya adalah anak yang akan melangsungkan perawinan menyatakan kehendak untuk berumah tangga dengan segala konsekwensinya atau telah siap lahir batin, merasa tidak melanggar hukum agama karena telah akil baligh, telah dilamar atau tunangan dan khawatir kalau terjerumus perbuatan yang dilarang agama, orang tua siap mendukung moril dan material dan lain sebagainya. Yang lebih parah lagi terkadang pihak wanita tersebut telah hamil sebelum mengajukan permohonan dispensasi kawin. Alasan-alasan tersebut sedikit banyak mempengaruhi sikap para hakim di Pengadilan yang ditunjuk dalam mengambil keputusan untuk memberikan izin dispensasi kawin bagi para pihak. Sementara itu setiap anak yang belum 
berumur 18 tahun harus mendapatkan perlindungan akan hak-hak anak dan kesejahteraan sebagaimana yang diamanatkan oleh Undang-undang Perlindungan Anak. Disadari oleh rasa keprihatinan yang mendalam atas berbagai pelanggaran terhadap hak-hak anak.

Disebutkan pula, penyelenggaraan perlindungan anak berasaskan Pancasila dan berlandaskan Undang-Undang Dasar Negara Republik Indonesia Tahun 1945 serta prinsip-prinsip dasar Konvensi Hak-Hak Anak meliputi:

a. Non diskriminasi;

b. Kepentingan yang terbaik bagi anak;

c. Hak untuk hidup, kelangsungan hidup, dan perkembangan; dan

d. Penghargaan terhadap pendapat anak.

Perlindungan anak bertujuan untuk menjamin terpenuhinya hak-hak anak agar dapat hidup, tumbuh, berkembang, dan berpartisipasi secara optimal sesuai dengan harkat dan martabat kemanusiaan, serta mendapat perlindungan dari kekerasan dan diskriminasi, demi terwujudnya anak Indonesia yang berkualitas, berakhlak mulia, dan sejahtera (vide pasal 3). Terkait pernikahan di bawah umur, pasal 26 (1) huruf (c ) UU Perlindungan Anak 2002 menyebutkan bahwa: Orang tua berkewajiban dan bertanggung jawab untuk : (c) mencegah terjadinya perkawinan pada usia anak-anak. ${ }^{5}$ Selanjutnya, di dalam undang-undang tersebut dinyatakan bahwa ada beberapa hak anak yang harus dipenuhi, yaitu :

1. Hak untuk mendapatkan pendidikan;

Anak berhak untuk mendapatkan pendidikan, jika anak yang dibawah umur telah menikah secara otomatis pendidikan anak tersebut terbengkalai karena mereka harus mengurusi anak dan suaminya. Padahal yang kita ketahui pendidikan sangat penting, karena pendidikan sebagai bekal di masa depan. Jadi anak berhak mendapatkan pendidikan.

2. Hak untuk berpikir dan berekspresi;

Sesuai UU No.23 Tahun 2002 tentang Perlindungan Anak disebutkan bahwa setiap anak berhak untuk berpikir dan berekspresi sesuai dengan tingkat kecerdasan dan usianya dalam bimbingan orangtuanya. Dengan pernikahan dibawah umur tentunya anak sudah tidak lagi bisa mengekspresi diri dan berpikir sesuai dengan usianya karena dituntut melaksanakan berbagai kewajiban sebagai seorang istri.

3. Hak untuk menyatakan pendapat dan didengar pendapatnya;

Dalam kasus pernikahan dibawah umur, perlu dipertanyakan apakah anak telah dimintai pendapatnya dan didengar pendapatnya. Sebab, pada kenyataannya orang dewasa cenderung memandang anak belum mampu menentukan keputusan sendiri, yang akhirnya orang dewasalah yang mengambil keputusan dan mengatasnamakan " kepentingan yang terbaik untuk anak". Padahal, banyak motif pernikahan anak dibawah umur berdasarkan kepentingan orang dewasa atau orangtua, umpamanya motif ekonomi.

4. Hak untuk beristirahat dan memanfaatkan waktu, bergaul dengan teman sebaya, bermain, berekspresi dan berkreasi; Dengan pernikahan dibawah umur, anak tidak lagi dapat memanfaatkan waktu luang dan bergaul, bermain serta berekpresi dengan teman-teman sebaya. Anak yang menikah dibawah umur di'karbit' menjadi orang dewasa yang mempunyai tanggungjawab terhadap rumah tangga, suami dan anak-ankanya. 
5. Hak untuk mendapatkan perlindungan

Hak perlindungan ini sejalan dengan Pasal 2 ayat (3)(4) UU tentang Kesejahteraan Anak, yang menyebutkan: " anak berhak atas pemeliharaan dan perlindungan, baik semasa dalam kandungan maupun sesudah dilahirkan. Anak berhak atas perlindungan-perlindungan terhadap lingkungan hidup yang dapat membahayakan dan menghambat pertumbuhan dan perkembangannya dengan wajar". "Anak mestinya dilindungi dari hal-hal yang membawa dampak negatif bagi perkembangannya, baik fisik maupun psikis. Dengan perkawinan dibawah umur, perlindungan orangtua yang tulus dan sejati menjadi berkurang karena beralih kepada suami. Anak seharusnya dilindungi dari pernikahan dini yang berdampak pada perkembangannya, baik secara fisik maupun psikis. UU No.23 Tahun 2002 Tentang Perlindungan Anak sudah memuat ancaman pidana bagi pelanggarannya.

Permohonan dispensasi kawin yang diajukan di pengadilan agama akan diproses melalui persidangan. Didalam persidangan, orang tua dan calon pengantin akan dimintakan penjelasan atas keadaan dan alasan yang diajukan permohonan dispensasi kawin. Pada keadaan yang dilematis ini, hakim Pengadilan Agama Limboto sebagai pihak yang berwenang dituntut untuk memutuskan mana yang lebih maslahah antara nikah di bawah umur dengan membiarkan mereka terjerumus kedalam perzinahan.

Pengadilan mempunyai kekuasaan dalam mengadili maupun menangani masalah permohonann dispensasi kawin yang mana hakim harus menafsirkan dan menimbang tentang putusan yang di ambil. Idealnya hakim dalam penetapan dispensasi kawin anak dibawah umur tetap mendasarkan pada pertimbangan yang sesuai dengan Undang-Undang Perkawinan Nomor 1 Tahun 1974, yaitu membatasi usia pernikahan minimal 19 tahun untuk laki-laki dan 16 tahun untuk perempuan. Usia dan kedewasaan menjadi hal penting yang harus diperhatikan bagi pria dan wanita yang ingin melangsungkan pernikahan.

Di Pengadilan Agama Limboto terdapat perkara Dispensasi Kawin pada tahun 2015 sejumlah 73 perkara dan pada tahun 2016 sejumlah 97 perkara, sehingga total perkara berjumlah 170 perkara permohonan dispensasi kawin. Dan dalam perkara yang ditangani tersebut 149 dikabulkan, 5 perkara ditolak, 3 perkara dicabut, 1 dicoret dan 1 dinyatakan tidak dapat diterima. 


\section{B. Kajian Teori}

1. Dispensasi Kawin

a. Perkara Voluntair

PerkaraVoluntairadalah merupakan perkara permohonan yang didalamnya tidak terdapat sengketa, sehingga tidak mempunyai lawan. Pada perkara permohonan tidak dapat diterima dalam proses Pengadilan, kecuali apabila ada kepentingan undang-undang yang menghendaki.

\section{b. Dispensasi Kawin}

Pengertian dispensasi kawin menurut kamus bahasa Indonesia, dispensasi merupakan izin pembebasan dari suatu kewajiban atau larangan. Jadi dispensasi merupakan kelonggaran terhadap sesuatu yang sebenarnya tidak diperbolehkan untuk dilakukan atau dilaksanakan.7

Dispensasi kawin merupakan dispensasi yang diberikan Pengadilan Agamakepada calon mempelai yang belum cukup umur untuk melangsungkan perkawinan, bagi pria yang belum mencapai 19 (sembilan belas tahun) tahun dan atau wanita belum mencapai 16 (enam belas ) tahun.8 Ini sebagaimana ketentuan pada Undang-undang Perkawinan pada Pasal 7 bahwa perkawinan baru boleh dilaksanakan apabila calon suami sudah berumur 19 tahun dan calon isteri sudah berumur 16 tahun.

Batasan umur suatu pernikahan dapat dilangsungkan pada usia 19 tahun (pria) dan 16 tahun (wanita) merupakan kategori pernikahan anak usia dini. Kalaupun pernikahan yang dilangsungkanbelum mencapai batasan umur tersebut (pria umur 19 tahun dan wanita umur 16 tahun) maka atas perkawinan tersebut termasuk dalam kategori pernikahan dibawah umur.

Pernikahan yang masih dibawah umur maka terlebih dahulu harus memohonkan dispensasi kawin di pengadilan, yang dalam hal ini adalah Pengadilan Agama/ Mahkamah Syar'iyah.

\section{Pemberian Dispensasi Kawin}

Menurut Undang-undang Perlindungan Anak. Undang-undang Nomor 23 tahun 2002 tentang Perlindungan anak dibuat berdasarkan empat prinsip (pasal 2 UU Perlindungan Anak ), yaitu :

a. Non-diskriminasi;

b. Kepentingan terbaik bagi anak;

c. Hak untuk hidup, kelangsungan hidup, dan perkembangan, dan;

d. Penghargaan terhadap anak.

Apabila melihat ketentuan Pasal 26 ayat 1 huruf c Undang-Undang Nomor 23 Tahun 2002 tentang Perlindungan Anak dengan tegas melarang terjadinya pernikahan anak di bawah umur yang belum mencapai usia 18 tahun, begitu juga batasan usia nikah dalam Pasal 7 ayat (1) UU Nomor 1 Tahun 1974. Namun, pada saat yang sama Pasal 7 ayat (2) UU Nomor 1 Tahun 1974 tentang Perkawinan di dalamnya juga memperbolehkan seseorang untuk mengajukan permohonan dispensasi Kawin. Sepintas ada kontradiksi antara Undang-Undang Perlindungan Anak dengan Undang-Undang Perkawinan perihal perkawinan anak di bawah umur. Untuk itu, 
adanya kontradiksi pasal-pasal dari kedua Undang-undang tersebut dibutuhkan ketelitian yang mendalam dalam mencari titik temu dalam penyelesaian dispensasi kawin.

Undang-Undang Perlindungan Anak tetap harus dijadikan sebagai bahan dalam memutuskan perkara yang berkaiatan dengan usia pernikahan, namun tetap saja tidak dapat menutup kemungkinan terjadinya dispensasi kawin yang juga memiliki sandaran yuridis dalam perundang-undangan. Perlu diketahui pula bahwa dispensasi kawin merupakan aturan khusus sementara Undang-undang perlindungan anak tepatnya Pasal 26 ayat (1) huruf c merupakan aturan yang bersifat umum. Perbedaan-perbedaan batas usia dewasa ini bukanlah merupakan hal yang salah, asalkan dalam implementasinya pada kepentingan-kepentingan yang dialami warga Negara Indonesia mengacu pada asas Lex specialist derogate legi generalis (hukum yang khusus menyampingkan hukum yang umum) dan dapat terwujud secara tepat sasaran.

Perkawinan di bawah umur jelas bertentangan dengan Undang-Undang No. 23 tahun 2002 Tentang Perlindungan Anak. Dalam Undang-Undang tersebut dijelaskan bahwa yang dinamakan anak adalah seseorang yang belum berusia 18 tahun. Dari pengertian anak tersebut, dapat dikatakan bahwa untuk seseorang yang belum berusia 18 tahun seharusnya memperoleh haknya yaitu berhak untuk dapat hidup, tumbuh, berkembang, dan berpartisipasi secara wajar sesuai dengan harkat dan martabat kemanusiaan, serta mendapat perlindungan dari kekerasan dan diskriminasi. Hak tersebut juga berkaitan dengan hak untuk memperoleh pendidikan yang layak. Hal inilah yang seharusnya menjadi pertimbangan, baik bagi pelaku perkawinan di bawah umur terlebih lagi bagi orang tua.

Peran orang tua sangat penting dalam pertumbuhan dan perkembangan anak yaitu berperan dalam mensosialisasikan nilai-nilai kebaikan dan norma yang berlaku atau yang diharapkan masyarakat kepada anak mereka yang dimulai dari masalah- masalah kecil yang terjadi dalam keluarga sesuai dengan tahap perkembangan usia anak. ${ }^{9}$ Tugas utama orang tua adalah mendidik anaknya menjadi generasi bangsa yang bermanfaat bagi orang lain. Hal inilah yang patut diperhatikan oleh para orang tua sekarang, dengan mendorong dan memotivasi anak dalam menggapai cita-citanya. Akan tetapi, terdapat beberapa faktor yang menyebabkan hal tersebut menjadi terbentur, yakni faktor ekonomi, adat dan budaya. ${ }^{10}$ Tidak hanya di kota-kota besar perkawinan di bawah umur juga terjadi dan dilakukan masyarakat Kabupaten Gorontalo. Hal ini dapat dilihat dari daftar perkara yang masuk di Pengadilan Agama Limboto mayoritas dilatar belakangi oleh anak para Pemohon telah menjalin hubungan asmara yang begitu dekat dan dikhawaatirkan akan terjadi perbuatan yang melanggar norma agama.

Oleh karena itu patut menjadi pertimbangan orang tua untuk tidak menikahkan anaknya di usia dini, sebagaimana diatur dalam UU No. 23 tahun 2002 bahwa : Orang tua berkewajiban dan bertanggung jawab untuk:

a. Mengasuh, memelihara, mendidik, dan melindungi anak;

b. Menumbuh kembangkan anak sesuai dengan kemampuan, bakat, dan minatnya; dan

c. Mencegah terjadinya perkawinan pada usia anak-anak. (Pasal 26 UU No. 23 tahun 2002)

Teori hokum yang erat kaitannya dalam membicarakan problematika perlindungan anak sebagai penegasan dalam tesis ini. Perlindungan hukum sebagai upaya melindung kepentingan seseorang dengan cara mencurahkan suatu kekuasaan kepadanya untuk bertindak dalam kepentingan tersebut, sehingga salah satu sifat dan sekaligus merupakan tujuan dari 
Jurnal Ilmiah Al-Jauhari (JIAJ)

Studi Islam dan Interdisipliner

Volume 3 No 2 September 2018

ISSN 2541-3430 E-ISSN 2541-3449

hukum yaitu perlindungan masyarakat akan tercapai. Masyarakat perlu dilindungi dari perbuatan sewenang-wenang dari pemerintah yang tidak sesuai dengan aturan sehingganya menciptakan ketertiban dan ketentraman sehingga memungkinkan manusia untuk menikmati martabatnya sebagai manusia. Undang-undang Perlindungan anak ini merupakan parameter yang digunakan peneliti untuk mengkaji penetapan hakim terhadap dispensasi kawin dalam tataran sosial kemasyarakatan, dengan berdasarkan pada perlindungan anak. 


\section{Metode Penelitian}

\section{Jenis dan Sifat Penelitian}

Jenis penelitian yang digunakan dalam penyusunan tesis ini penelitian lapangan (field research), yaitu data yang dihimpun atau dikumpulkan dari lapangan untuk memperoleh informasi dan data yang valid yang diperlukan untuk menjawab masalah dalam penelitian ini. Sifat penelitian yang digunakan adalah deskriptif-analitik yaitu penelitian untuk menyelesaikan masalah dengan cara mendiskripsikan masalah melalui pengumpulan, penyusunan, dan penganalisisan data, kemudian dijelaskan dan selanjutnya memberi penilaian terhadap persoalan penelitian.

\section{Pendekatan}

Pendekatan yang digunakan dalam penelitian ini adalah pendekatan normatif yaitu pendekatan yang melihat hukum sebagai suatu sistim yang utuh, meliputi asas-asas hukum, norma-norma hukum, dan aturan yang bersifat tertulis maupun tidak tertulis. Dalam Penelitian ini berfokus pada peraturan yang berkaitan dengan dispensasi nikah.

\section{Sumber Data}

Secara garis besar sumber data yang digunakan dalam penelitian ini diklasifikasikan menjadi sumber data primer dan sumber data sekunder, dan sumber data tersier. Sumber data primer dalam penelitian ini yaitu hasil wawancara dengan beberapa hakim Pengadilan Agama Limboto dan putusan Pengadilan Agama Limboto sedangkan sumber data sekundernya yaitu hasil penelitian, undang-undang ataupun buku yang berkaitan dengan dispensasi nikah. Data tersier,berupa bahan-bahan yang membantu dalam memberi petunjuk dan penjelasan terhadap data primer dan data sekunder, seperti kamus hukum, kamus besar bahasa Indonesia, dan berbagai kamus lain yang mendukung penelitian ini.

\section{Metode Pengumpulan Data}

\section{a. Interview}

Dalam penelitian ini peneliti menggunakan bentuk wawancara mendalam (indepth interview), dengan tujuan untuk mengetahui pertimbangan hukum hakim dalam perkara dispensasi nikah dan metode penemuan hukum dalam mengkabulkan ataupun menolak permohonan dispensasi nikah. Adapun yang diwawancarai yakni 5 hakim Pengadilan Agama Limboto sebagai ketua-ketua majelis hakim.

\section{b. Dokumentasi}

Yaitu mengumpulkan data-data dan bahan berupa arsip-arsip. Dalam hal ini berupa dokumen penetapan dispensasi yang dikabulkan maupun ditolak dari pengadilan agama Limboto dan laporan perkara yang diterima menurut jenisnya.

\section{Teknik Analisis Data}

Teknik analisis data yang digunakan adalah metode analisis data kualitatif, dengan menggunakan alur berfikir: Induktif, yaitu cara berfikir yang bertolak dari hal-hal yang bersifat khusus kemudian digeneralisasikan ke dalam kesimpulan yang umum. Dalam hal ini yang dianalisis adalah bagaimana interpretasi hakim dalam mengabulkan permohonan dispensasi nikah kemudian dikaitkan dengan alasan mengajukan dispensasi nikah serta siap yang lebih dominan dalam mengajukan permohonan dispensasi nikah. 
Deduktif, Yaitu suatu metode menganalisis data yang bersifat umum kemudian diambil kesimpulan yang khusus dengan menggunakan perundang-undangan yang berlaku untuk menguatkan analisis dalam penelitian ini. Teknik ini digunakan untuk menganalisis data-data yang didapatkan dengan teori-teori yang digunakan.

Teknik Interpretasi Data Setelah dipaparkan data yang spesifik secara rinci pada tahap ini peneliti menginterpretasikan data untuk mendeskripsikan data pada bagian hasil penelitian dan pembahasan

Pengambilan Kesimpulan pada tahap akhir ini peneliti menarik kesimpulan dari datadata yang sudah dikumpulkan serta dianalisis sehingga mendapatkan gambaran akhir tentang pertimbangan hakim dalam mengabulkan atau menolak permohonan dispensasi kawin dan metode penemuan hukum yang digunakan hakim dalam menetapkan permohonan dispensasi kawin. 


\section{HASIL PENELITIAN}

\section{Deskripsi Penetapan Permohonan Dispensasi Kawin pada Pengadilan Agama Limboto}

Permohonan dispensasi kawin di Pengadilan Agama Limboto setiap tahun semakin meningkat, hal ini terlihat jelas dari banyaknya perkara yang masuk. Pada Tahun 2015 perkara dispensasi kawin yang masuk sejumlah 73 perkara permohonan dan di Tahun 2016 naik menjadi 93 perkara. 73 perkara yang masuk pada Tahun 2015 telah diputus diterima oleh Pengadilan Agama Limboto sejumlah 63 perkara, ditolak sejumlah 3 perkara, digugurkan 5 perkara, dicabut 1 perkara dan dicoret dari register 1 perkara. Sedangkan pada tahun 2016 telah diterima oleh Pengadilan Agama Limboto sejumlah 86 perkara, ditolak 2 perkara, digugurkan 1 perkara, dicabut 2 perkara, dicoret 1 perkara, dan tidak dapat diterima 1 perkara. Sehingga dari 2 tahun terakhir tercatat jumlah perkara dispensasi kawin 166 perkara, dan yang telah dikabulkan 149 perkara, dan yang ditolak 5 perkara, 6 perkara yang digugurkan, 3 perkara yang dicabut, 1 perkara yang dicoret dan 1 perkara yang tidak dapat diterima. Dari 149 perkara dispensasi kawin penulis membatasi penelitian ini pada 11 penetapan dispensasi kawin yang menurut penulis penetapan tersebut representasi dari perkara dispensasi kawin yang ada di Pengadilan Agama Limboto, yaitu 5 perkara yang dikabulkan, dan 4 perkara yang ditolak.

Berdasarkan data yang berhasil di himpun menunjukan fakta bahwa terdapat beberapa hal yang mempengaruhi keberhasilan dan kegagalan dalam pelaksanaannya Salim ${ }^{11}$ menegaskan meliputi substansi hukum, struktur, dan kultur hukum. Substansi hukum yaitu peraturan yang akan ditegakkan harus jelas dan tidak menimbulkan multitafsir. Struktur hukum yaitu aparatnya menegakkan hukum secara konsisten. Kultur hukum yaitu masyarakat yang terkena hukum mendukungnya Sejalan dengan pemikiran di atas, Sabian Usman menyebutkan bahwa tiga pilar utama dalam penegakan hukum meliputi; Perundang-undangan atau substansi hukum yang akan ditegakkan, Aparat penegak hukumnya, dan kultur masyarakat tempat nilai-nilai hukum akan ditegakkan. ${ }^{12}$ Struktur hukum tidak akan berjalan dengan baik kalau tidak ditunjang oleh adanya substansi hukum yang baik pula. Demikian pula substansi hukum yang baik tidak akan dapat dirasakan manfaatnya kalau tidak ditunjang oleh struktur hukum yang baik. Struktur dan substansi hukum tidak akan dapat dirasakan eksistensinya kalau tidak didukung oleh budaya hukum masyarakat yang baik. Dengan kata lain, hukum akan berjalan efektif manakala ketiga aspek hukum di atas saling berinteraksi dan memainkan peran sesuai dengan fungsinya. Ibarat seekor ikan, ia akan hidup dengan baik manakala ditunjang oleh kualitas air kolam yang baik dan makanan yang baik pula. Apabia ketiga subsistem hukum tidak berfungsi dengan baik, maka akan muncul permasalahan dalam upaya mengimplementasikan hukum sebagai sarana pembangunan masyarakat itu sendiri. 
Dibawah ini adalah tabel perkara-perkara yang dikabulkan dan ditolak dalam permohonan dispensasi kawin di Pengadilan Agama Limboto.

\begin{tabular}{|c|c|c|c|c|}
\hline No & Permohonan Nomor & $\begin{array}{c}\text { Alasan } \\
\text { Permohonan }\end{array}$ & Hasil Putusan & Ket \\
\hline 1. & 092/Pdt.P/2015/PA Lbt. & Pacaran 1 tahun & $\begin{array}{l}\text { Mengabulkan dengan } \\
\text { alasan kemaslahatan }\end{array}$ & \\
\hline 2. & 102/Pdt.P/2015/PA Lbt. & Hamil 4 bulan & $\begin{array}{l}\text { Mengabulkan dengan } \\
\text { alasan kemaslahatan }\end{array}$ & \\
\hline 3. & 146/Pdt.P/2016/PA Lbt. & Hamil 7 bulan & $\begin{array}{l}\text { Mengabulkan dengan } \\
\text { alasan kemaslahatan }\end{array}$ & \\
\hline 4. & 171/Pdt.P/2016/PA Lbt & Hamil 3 bulan & $\begin{array}{l}\text { Mengabulkan dengan } \\
\text { alasan kemaslahatan }\end{array}$ & \\
\hline 5. & 176/Pdt.P/2016/PA Lbt & Hamil 3 bulan & $\begin{array}{l}\text { Mengabulkan dengan } \\
\text { alasan kemaslahatan }\end{array}$ & \\
\hline 6. & 009/Pdt.P/2015/PA Lbt. & Hamil 3 bulan & $\begin{array}{l}\text { Menolak karena } \\
\text { hubungan sesusuan }\end{array}$ & \\
\hline 7. & 024/Pdt.P/2015/PA Lbt & $\begin{array}{l}\text { Kelas Ujian } \\
\text { Pacaran normal }\end{array}$ & $\begin{array}{l}\text { Menolak karena } \\
\text { kepentingan anak }\end{array}$ & \\
\hline 8. & 026/Pdt.P/2015/PA Lbt & Hamil 2 bulan & $\begin{array}{l}\text { Menolak karena } \\
\text { tidak dapat } \\
\text { dibuktikan }\end{array}$ & \\
\hline 9. & 111/Pdt.P/2016/PA Lbt & Hamil 5 bulan & $\begin{array}{l}\text { Menolak karena } \\
\text { tidak dapat } \\
\text { dibuktikan }\end{array}$ & \\
\hline
\end{tabular}




\begin{tabular}{|l|l|l|l|} 
& & & \\
\hline Total & Jumlah & 9 & \\
\hline
\end{tabular}

Ket : Sumber data Primer hasil wawancara, 2017

Dalam kaitannya dengan menerima atau mengabulkan permohonan dispensasi kawin, ada hal penting yang menjadi catatan penulis berdasarkan data-data diatas, yaitu:

1. Dispensasi kawin yang diterima di Pengadilan Agama Limboto tetap mengacu pada ketentuan dalam

Undang-Undang Perkawinan, khususnya yang secara tegas disebutkan dalam Pasal 7 ayat (1) dan ayat (2).

2. Kesiapan dan kesanggupan anak pemohon untuk menjalani rumah tangga ditandai dengan pekerjaan yang dimiliki dan keinginan kuat untuk menikah.

3. Asas kemaslahatan ditonjolkan oleh hakim dalam mengabulkan perkara dispensasi kawin, terlebih keadaan si anak yang telah hamil dan anak yang masih dalam kandungan.

Melihat alasan hakim dalam mengabulkan permohonan dispensasi kawin ini, perlindungan anak menjadi hal yang utama yang harus dipenuhi Pemohon karena perlindungan sebagaimana diatur oleh Undang-Undang Nomor 23 Tahun 2002 tentang Perlindungan Anak. Menurut Undangundang ini "anak adalah seseorang yang belum berusia 18 tahun, termasuk anak yang masih dalam kandungan" (Pasal 1 ayat (1)) dan "perlindungan anak adalah segala kegiatan untuk menjamin dan melindungi anak dan hak-haknya agar dapat hidup, tumbuh, berkembang, dan berpartisipasi secara optimal sesuai dengan harkat dan martabat kemanusiaan, serta mendapat perlindungan dari kekerasan dan diskriminasi" (Pasal 1 ayat (2)).13 Dari ketentuan UndangUndang Nomor 23 Tahun 2002 dapat diketahui bahwa anak yang ada dalam kandungan hingga berusia 18 tahun mendapat perlindungan akan hak-hak hidup, tumbuh, dan berkembang, serta dari berbagai kekerasan dan diskriminasi.

\section{a. Pertimbangan yang dijadikan dasar ditolak}

Pertimbangan yang dijadikan dasar majelis hakim untuk menolak perkara ini pada ketidakhadiran pemohon pada agenda pembuktian serta tidak adanya kejelasan ataupun keterangan yang disampaikan ke pengadilan mengenai ketidakhadirannua tersebut telah menunjukkan pemohon sendiri yang menghambat proses pemeriksaannya menjadi berlarut larut.14

Selain itu menurut majelis hakim bahwa dalam menerapkan Undang-Undang Nomor 1 Tahun 1974 dalam perkara dispensasi kawin, maka pengadilan harus lebih mencermati alasan-alasan dan kesiapan anak pemohon dengan calon suaminya yang berkeinginan untuk tetap menikah meski usia anak pemohon belum mencukupi batas dalam Undang-Undang Perkawinan. 
Berdasarkan data-data yang dipaparkan diatas tentang perkara dispensasi kawin yang ditolak oleh pengadilan Agama Limboto dapat dilihat dalam tabel berikut:

\begin{tabular}{|l|l|l|l|}
\hline No & Perkara & $\begin{array}{l}\text { Alasan } \\
\text { DK }\end{array}$ & $\begin{array}{l}\text { Pertimbangan } \\
\text { Hakim }\end{array}$ \\
\hline 1 & $\begin{array}{l}\text { 009/Pdt.P } \\
\text { /2015 } \\
\text { /PA Lbt }\end{array}$ & $\begin{array}{l}\text { Pacaran sudah } \\
\text { Bulan Hamil }\end{array}$ & $\begin{array}{l}\text { - Hubungan } \\
\text { sesusuan }\end{array}$ \\
& & & \\
\end{tabular}

Bentuk penolakan mengacu pada perlindungan anak dari hukum, baik itu terkait dengan hukum Islam dan hukum acara yang berlaku di Pengadilan. 4 kasus yang ditolak, kasus pertama adanya hubungan sesusuan telah mengharamkan kedua anak tersebut untuk melangsungkan pernikahan, kasus kedua adanya faktor pendidikan anak, ketiga dan keempat adanya ketidak hadiran pemohon membuat perkara ini tidak melalui proses pembuktian sehingga harus ditolak. berikut:

Dalam pertimbangannya, hakim telah menolak permohonan dengan alasan-alasan sebagai

1. Antara anak Pemohon dengan calon isterinya terdapat hubungan sesusuan

2. Masih berstatus sebagai pelajar Sekolah Menengah Pertama (SMP) yakni anak Pemohon kelas 2 sedangkan calon suaminya kelas 3, bahkan menurut calon suami, dirinya akan mengikuti ujian Nasional.

3. Menolak perkara ini pada ketidakhadiran pemohon pada agenda pembuktian serta tidak adanya kejelasan ataupun keterangan yang disampaikan

kepengadilanmengenai

ketidakhadirannua tersebut telah menunjukkan pemohon sendiri yang menghambat proses pemeriksaannya menjadi berlarut larut.

Melihat alasan-alasan hakim dalam menolak perkara ini terkait dengan hukum Islam dan hukum acara yang berlaku di Pengadilan Agama. Terkait dengan adanya dalil-dalil yang diajukan sebagaimana dalam surat permohonan pemohon harus dihubungkan dengan peristiwa hukum yang terjadi dan dikorelasikan dengan hukum yang berlaku.

Undang-Undang Republik Indonesia Nomor 1 Tahun 1974 tentang perkawinan bahwa perkawinan dilarang antar dua orang yang :

a. berhubungan darah dalan garis keturunan lurus ke bawah atau ke atas;

b. berhubungan darah dalam garis keturunan menyamping yaitu antara saudara, antara seorang dengan seorang saudara orang tua dan antara seorang dengan saudara neneknya;

c. berhubungan semenda, yaitu mertua, anak tiri, menantu dan ibu/bapak tiri;

d. berhubungan susuan, anak susuan, saudara dan bibi/paman susuan; 
e. berhubungan saudara dengan isteri atau sebagai bibi atau kemenakan dari isteri, dalam hal seorang suami beristeri lebih dari seorang;

f. yang mempunyai hubungan yang oleh agamanya atau praturan lain yang berlaku dilarang kawin.

Selanjutnya, di dalam undang-undang Perlindungan anak dinyatakan bahwa ada beberapa hak anak yang harus dipenuhi, yaitu :

1. Hak untuk mendapatkan pendidikan;

Anakberhakuntuk

mendapatkan pendidikan, jika anak yang dibawah umur telah menikah secara otomatis pendidikan anak tersebut terbengkalai karena mereka harus mengurusi anak dan suaminya. Padahal yang kita ketahui pendidikan sangat penting, karena pendidikan sebagai bekal di masa depan. Jadi anak berhak mendapatkan pendidikan.

2. Hak untuk berpikir dan berekspresi; Sesuai UU No.23 Tahun 2002

tentang Perlindungan Anak disebutkan bahwa setiap anak berhak untuk berpikir dan berekspresi sesuai dengan tingkat kecerdasan dan usianya dalam

bimbingan orangtuanya. Dengan pernikahan dibawah umur tentunya anak sudah tidak lagi bisa mengekspresi diri dan berpikir sesuai dengan usianya karena dituntut melaksanakan berbagai kewajiban sebagai seorang istri.

3. Hak untuk menyatakan pendapat dan didengar pendapatnya;

Dalam kasus pernikahan dibawah umur, perlu dipertanyakan apakah anak telah dimintai pendapatnya dan didengar pendapatnya. Sebab, pada kenyataannya orang dewasa cenderung memandang anak belum mampu menentukan keputusan sendiri, yang akhirnya orang dewasalah yang mengambil keputusan dan mengatasnamakan " kepentingan yang terbaik untuk anak". Padahal, banyak motif pernikahan anak dibawah umur berdasarkan kepentingan orang dewasa atau orangtua, umpamanya motif ekonomi. Hak untuk beristirahat dan memanfaatkan waktu, bergaul dengan teman sebaya, bermain, berekspresi dan berkreasi;

Dengan pernikahan dibawah umur, anak tidak lagi dapat memanfaatkan waktu luang dan bergaul, bermain serta berekpresi dengan teman-teman sebaya. Anak yang menikah dibawah umur di'karbit' menjadi orang dewasa yang mempunyai tanggungjawab terhadap rumah tangga, suami dan anak-anaknya.

4. Hak untuk mendapatkan perlindungan Hak perlindungan ini sejalan dengan Pasal 2 ayat (3)(4) UU tentang Kesejahteraan Anak, yang menyebutkan: " anak berhak atas pemeliharaan dan perlindungan, baik semasa dalam kandungan maupun sesudah dilahirkan. Anak berhak atas perlindungan-perlindungan terhadap lingkungan hidup yang dapat membahayakan dan menghambat pertumbuhan dan perkembangannya dengan wajar". Anak mestinya dilindungi dari hal-hal yang membawa dampak negatif bagi perkembangannya, baik fisik maupun psikis. Dengan perkawinan dibawah umur, perlindungan orangtua yang tulus dan sejati menjadi berkurang karena beralih kepada suami. Anak seharusnya dilindungi dari pernikahan dini yang berdampak pada perkembangannya, baik secara fisik maupun psikis. UU No.23 Tahun 2002 Tentang 
Perlindungan Anak sudah memuat ancaman pidana bagi pelanggarannya. Dalam permasalahan pernikahan anak dibawah umur, dalam pasal 82 UU Perlindungan Anak dinyatakan bahwa barang siapa melakukan bujukrayu, tipu muslihat, serangkaian kebohongan, atau membujuk anak untuk melakukan atau membiarkan dilakukannya perbuatan cabul, maka dapat dijerat pidana penjara 3-15 tahun dan denda balik banyak Rp.300.000.000,00-dan paling sedikit Rp.60.000.000,00.

Menurut peneliti apa yang telah dipertimbangkan oleh majelis hakim dalam permohonan dispensasi kawin telah memenuhi hak anak dari segi Hak untuk menyatakan pendapat dan didengar pendapatnya dan Hak untuk mendapatkan perlindungan.

Menurut Soetjipto Rahardjo, bahwa perlindungan hukum adalah adanya upaya melindungi kepentingan seseorang dengan cara mengalokasikan suatu kekuasaan kepadanya untuk bertindak dalam kepentingan tersebut. Sehingga salah satu sifat dan sekaligus merupakan tujuan dari hukum adalah memberikan perlindungan (pengayoman) kepada masyarakat. 15 Sehingga perlindungan hukum bagi anak adalah usaha-usaha untuk memproteksi hak-hak anak dengan memberikan hak anak secara proporsional. Penerapan Perlindungan Anak dalam Perkara dispensasi kawin dapat diklasifikasikan sebagai berikut berdasarkan hak-hak anak:

\section{Dispensasi Kawin sebagai bentuk Kepentingan yang Terbaik Bagi Anak.}

Anak sebagai subjek yang menjadi pelaku utama dalam membangun rumah tangga yang baru, sehingga persoalan ini menjadi pelik untuk diselesaikan di Pengadilan Agama Limboto. Penolakan yang telah dilakukan oleh KUA tidak menghambat proses pernikahan karena negara telah memberikan ruang dalam Undang-Undang Perkawinan.

Terhadap 5 perkara yang dikabulkan di Pengadilan Agama Limboto, peneliti menilai bahwa pemberian dispensasi kawin terhadap anak telah dipertimbangkan secara matang oleh hakim sesuai dengan peraturan dan perundang-undangan yang berlaku. begitu juga dengan 4 perkara yang ditolak, semuanya untuk kepentingan terbaik bagi anak.

Menurut peneliti anak dalam hal ini mengalami posisi yang dilematis untuk kawin karena terbentur dengan usia pernikahannya, ada pria yang masih berumur 17 tahun dan berumur 18 tahun, sedangkan wanita ada yang berumur 14 tahun dan 15 tahun. Dan ini

telah ditempuh dengan jalan permohonan dispensasi kawin. Ada kepentingan yang ingin diwujudkan oleh anak melalui lembaga pernikahan yang sah. Hal ini merupakan wujud

2. ketaatan dari Undang-Undang Perkawinan Nomor 1 Tahun 1974 Pasal 7 Ayat 2 yang berbunyi : "Dalam hal penyimpangan terhadap ayat 1 pasal ini dapat meminta dispensasi kepada pengadilan atau pejabat lain yang ditunjuk oleh kedua orang tua pihak pria maupun pihak wanita. Melihat hubungan yang tidak sehat dari anak dengan pasangannya hingga menyebabkan kehamilan ataupun bahkan tidak hamil adalah hal yang harus diselamatkan. Dengan memberikan dispensasi kawin bagi anak akan lebih menjaga hubungan keduanya dari perbuatan tercela. Anak akan dilindungi dari aib, celaan yang datang dari luar, bahkan janin yang dikandung pun akan terlindungi dengan dispensasi kawin sebagai. Sehingga anak menjadi sejahtera melalui dispensasi kawin. Kesejahteraan anak adalah suatu tata kehidupan dan penghidupan anak yang dapat menjamin pertumbuhan dan perkembangan dengan wajar, baik secara rohaniyah, jasmaniyah maupun sosialnya. 


\section{Dispensasi Kawin sebagai bentuk pemberian hak untuk hidup, kelangsungan hidup, dan perkembangan anak.}

Disusunnya undang-undang perlindungan anak adalah untuk menjamin terwujudnya kehidupan yang ideal bagi anak dan bukan untuk melegitimasi kehendak anak yang tidak wajar, seperti keinginan untuk segera menikah di usia anak-anak. Dasar pertimbangan disahkannya undang-undang perlindungan anak yang diantaranya adalah bahwa anak adalah tunas, potensi, dan generasi muda penerus cita-cita perjuangan bangsa, memilikir peran strategis dan mempunyai ciri dan sifat khusus yang menjamin kelangsungan eksistensi bangsa dan negara pada masa depan. Agar setiap anak kelak mampu memikul tanggungjawab tersebut, maka ia perlu mendapatkan kesempatan yang seluas-luasnya untuk dan berkembang secara optimal, baik fisik mental maupun sosial. Oleh karena itu perkawinan harus dihindari dan merupakan jalan alternatif terakhir. Para pihak yang mempunyai otoritas dispensasi kawin harus berbuat yang terbaik untuk kepentingan masa depan anak bukan kepentingan sesaat.

\section{Dispensasi Kawin sebagai bentuk Penghargaan Terhadap Pendapat Anak}

Anak sebagai calon suami dan istri akan diambil keterangannya dalam permohoan dispensasi kawin, sehingga ada didengar pendapat dari kedua anak tersebut. Ada Pendapat-pendapat yang disampaikan oleh anak dalam permohonan dispensasi kawin, yaitu:

1. Kehendak atau kesepakatan berumah tangga dengan segala kosekuensinya.

2. Tidak ada halangan menikah, kedua calon mempelai tidak ada hubungan darah atau nasab, tidak ada hubunga semenda, tidak ada hubungan sesusuan.

3. Keduanya telah siap lahir batin atau fisik dan psikis serta telah akil baligh

4. Telah erat hubungannya dan dikhawatirkan melanggar norma agama.

5. Berpenghasilan yang cukup dan disetujui oleh orangtua.

6. Telah hamil.

Persetujuan anak atau kesepakatan bersama kedua belah pihak dalam membangun rumah tangga adalah kunci kebahagiaan keduanya. Meskipun undang-undang perkawinan dengan jelas telah mengatur bahwa perkawinan hanya diijinkan jika pihak pria sudah mencapai umur 19 tahun dan wanita mencapai umur 16 tahun (Pasal 7 ayat 1), akan tetapi muncul juga aturan bahwa perkawinan didasarkan pada persetujuan kedua calon mempelai (Pasal 6 ayat 1). Hal ini tentu bisa menjadi celah bagi dikabulkannya permohonan dispensasi kawin yang diajukan pemohon.

Dengan demikian bentuk penolakan dari majelis hakim pengadilan Agama Limboto erat kaitannya untuk memenuhi hak anak yaitu Hak untuk mendapatkan pendidikan, hak untuk hidup dan hak untuk beristirahat dan memanfaatkan waktu, bergaul dengan teman sebaya, bermain, berekspresi dan berkreasi. 


\section{E. Penutup}

\section{A. Kesimpulan}

Berdasarkan uraian-uraian peneliti di atas dapat disimpulkan bahwa pernikahan anak secara normative dalam perkara dispensasi nikah tidak relevan dengan tujuan perlindungan hokum terhadap anak. Undang undang perlindungan anak tidak menyinggung tentang dispensasi nikah, sebaliknya undang-undang perlidungan anak tidak mengintegrasikan perlindungan anak dan dispensasi nikah terhadap anak di bawah umur. Sehingga kedua peraturan ini belum melindungi kepentingan anak dalam perkara dispensasi nikah.

Penetapan dispensasi nikah memiliki efektifitas yang telah disandingkan dengan anak yang cukup dan matang dalam membangun keluarga yan baru. Hal ini perlu drespon oleh Negara dengan menghadirkan instrument khusus untuk anak dalam hal perlindungan yang lebih komprehensif dan tidak membenturkan undang-undang yang satu denganyang lainnya.

\section{B. Saran}

1. Diperlukan adanya titikk temu yang harmonis antara undang-undang perlindungan anak dengan undang-undang perkawinan

2. Norma perlindungan anak yang terkandung dalam undang-undang perlindungan anak perlu direvisi. 